\title{
Effects of bioturbation by three macrozoobenthic species and predation by necto-benthic mysids on cladoceran benthic eggs
}

\author{
Satu Viitasalo* \\ Tvärminne Zoological Station, University of Helsinki, 10900 Hanko, Finland, and Finnish Institute of Marine Research, \\ PO Box 2, 00561 Helsinki, Finland
}

\begin{abstract}
The effects of bioturbation and predation by the amphipod Monoporeia affinis, the bivalve Macoma balthica and the polychaetes Marenzelleria spp. were studied on the number, vertical distribution and hatching of benthic eggs (ephippia) of the cladoceran Bosmina longispina maritima. It was hypothesised that the 3 functionally different macrobenthic species affect Bosmina ephippia to different degrees. In addition, it was hypothesised that macrofaunal bioturbation either inhibits or enhances predation by the necto-benthic mysid Mysis mixta on cladoceran benthic eggs. $M$. affinis and $M$. balthica caused a 48 and $23 \%$ decrease in the total number of Bosmina ephippia, respectively, indicating egg predation. In addition, $M$. balthica extended the distribution of eggs into deeper sediment layers. Both $M$. affinis and $M$. balthica suppressed the daily hatching rate of Bosmina, and the effect of the bivalves (reduction 92\%) was stronger than that of the amphipods (34 to $78 \%$ ). None of the benthic species promoted the predation of mysids on Bosmina eggs. Instead, both $M$. affinis and $M$. balthica reduced the number of ephippia in the sediment surface (by 79 and $43 \%$, respectively), implying that these species decrease the ability of mysids to feed on cladoceran benthic eggs. $M$. balthica was the most harmful species for the recruitment of Bosmina, whereas the nonindigenous Marenzelleria spp. did not affect ephippia.
\end{abstract}

KEY WORDS: Bosmina ephippia $\cdot$ Bioturbation $\cdot$ Macrofauna $\cdot$ Mysids $\cdot$ Recruitment Resale or republication not permitted without written consent of the publisher

\section{INTRODUCTION}

The production of dormant eggs is an important means for zooplankton to escape unfavourable conditions, e.g. decreasing temperature and deteriorating food conditions (Marcus \& Boero 1998). High numbers of zooplankton resting stages have been recovered in marine (Onbé 1985), brackish (Viitasalo \& Katajisto 1994) and limnetic sediments (De Stasio 1989). Various benthic processes affect the viability and recruitment of dormant eggs from bottom sediments to plankton (Marcus \& Boero 1998), which, in turn, may be crucial for the success of subsequent generations (De Stasio 1989).

Translocation of zooplankton eggs in the sediment is a critical factor since eggs may hatch only when close to the sediment-water interface, presumably mainly due to the supply of dissolved oxygen (Uye et al. 1979,
Kankaala 1983). High sedimentation rates typical of the northern Baltic Sea (>10 $\mathrm{g} \mathrm{m}^{-2} \mathrm{~d}^{-1}$; Heiskanen \& Tallberg 1999) cause a rapid burial of settling particles. Moreover, soft-bottom macrofauna actively rework their habitat, changing the physical structure, layering and oxygen content of the sediment (Rhoads 1974). Certain deposit-feeding polychaete species transport copepod eggs upwards (Marcus \& Schmidt-Gengenbach 1986), whereas the amphipod Monoporeia affinis (hereafter Monoporeia) has been considered to bury eggs in Baltic sediments (Albertsson \& Leonardsson 2000). In addition to vertical movements, predation may also play a role, as benthic deposit-feeders may ingest dinoflagellate cysts (Persson \& Rosenberg 2003), copepod eggs (Parker et al. 1996) and ephippia (benthic eggs shielded by a transparent membrane) of daphnid cladocerans (Cáceres \& Hairston 1998). Moreover, Albertsson \& Leonardsson (2001) observed a neg- 
ative effect of Monoporeia on the hatching of the brackish water cladoceran Bosmina longispina maritima (hereafter Bosmina) and suggested that it resulted from predation by the amphipods. However, the mechanism underlying this observation remains unclear.

Besides infauna, epifaunal predators may affect the sediment surface properties. The necto-benthic mysid Mysis mixta is mainly a zooplanktivore (Viherluoto et al. 2000), but spends a large proportion of its life in the vicinity of the sea floor. To date, however, information on the overall impact of pelagic mysids on benthic habitats is limited (Albertsson 2004, Roast et al. 2004). Recently, M. mixta was found to eat Bosmina ephippia distributed on the sediment surface (Viitasalo \& Viitasalo 2004). In contrast, mysids appeared incapable of feeding on ephippia that were mixed within the sediment, suggesting that the vertical distribution of sedimented ephippia is crucial not only for the recruitment of cladocerans but also for the rate of epibenthic predation by mysids (Viitasalo \& Viitasalo 2004).

The effects of bioturbation on the movement of sediment particles have been investigated intensively during the few last years. Nevertheless, few data exist on the impact of various benthic taxa on zooplankton propagules and even less on cladoceran resting eggs, which are relatively large (e.g. Bosmina ephippia: $\sim 400 \mu \mathrm{m})$. The objective of the present study was to reveal how 3 functionally different zoobenthic speciesthe mobile surface deposit-feeding Monoporeia, the semi-mobile suspension- and deposit-feeding bivalve Macoma balthica (hereafter Macoma) and the nonindigenous deep-burrowing polychaetes Marenzelleria spp. (hereafter Marenzelleria) — affect the vertical distribution, abundance and recruitment of Bosmina ephippia in the sediment. In addition, the aim was to define the effect of bioturbation on the ability of mysids to reach Bosmina benthic stages. It was hypothesised that due to their different feeding and burrowing modes, the 3 benthic species have different impacts on Bosmina ephippia.

Two separate experiments were conducted, one examining the effects of benthic animals and mysids on the vertical distribution and abundance of Bosmina ephippia (bioturbation experiment, BE) and another examining the effect of Monoporeia and Macoma on the recruitment of Bosmina (hatching experiment, $\mathrm{HE}$ ). Experiments were done during 2003 and 2004 at the Tvärminne Zoological Station (University of Helsinki), southwestern coast of Finland.

\section{MATERIALS AND METHODS}

Natural history of the experimental species. During the last few decades, soft-bottom macrofaunal commu- nities of the northern Baltic Sea have experienced broad-scale changes, driven by eutrophication and changes in the deep-water salinity (Laine et al. 1997). Monoporeia, previously a numerical dominant of benthic communities over large areas, has drastically decreased, while Macoma has gradually increased in importance in many coastal habitats and may form almost monospecific communities (Perus \& Bonsdorff 2004). Furthermore, polychaetes from the genus Marenzelleria have spread rapidly since their introduction to the Baltic Sea in the 1980s (Bastrop \& Blank 2006). The densities range from less than 100 up to 10000 ind. $\mathrm{m}^{-2}$ for Monoporeia, to 2000 ind. $\mathrm{m}^{-2}$ for Macoma and to 5000 ind. $\mathrm{m}^{-2}$ for Marenzelleria (Cederwall et al. 1999, Kangas et al. 2001, Zettler et al. 2002).

Field collections. Zoobenthos, mysids and muddy surface sediment $(15 \%$ loss on ignition of dry weight after $2 \mathrm{~h}$ at $550^{\circ} \mathrm{C}$ ) with Bosmina ephippia were collected from soft-bottom areas in the Gulf of Finland $\left(59^{\circ} \mathrm{N}, 23^{\circ} \mathrm{E}\right)$ and in the Bothnian Sea $\left(61^{\circ} \mathrm{N}, 20^{\circ} \mathrm{E}\right)$ from depths of 35 to $100 \mathrm{~m}$. An Ockelmann benthic sledge (mouth opening $12 \times 30 \mathrm{~cm}$, net length $52 \mathrm{~cm}$, mesh size $150 \mu \mathrm{m}$ ) was used to collect surface layers of the sediment (approximately the upper $5 \mathrm{~cm}$ ) containing high densities of Bosmina eggs. The sediment was kept in cool boxes to retain the prevailing temperature $\left(\sim 5^{\circ} \mathrm{C}\right)$ until it was transported to the laboratory for processing. Macoma was collected with a bottom trawl (length $7 \mathrm{~m}$, width $4 \mathrm{~m}$, mesh size $10 \mathrm{~mm}$ ) and Mysis mixta with an epibenthic sledge (mouth opening $41 \times$ $23 \mathrm{~cm}$, net length $115 \mathrm{~cm}, 1 \mathrm{l}$ cod end). Monoporeia and Marenzelleria were taken with a van Veen grab. Sediment was put into $90 \mathrm{l}$ buckets filled with seawater, and the fragile amphipods and polychaetes were gently picked up under water by small sieves. In the field, all animals were immediately transferred into cool boxes with seawater from below the thermocline (5 to $10^{\circ} \mathrm{C}$ ), and for macrofauna, some sediment from the grab was added.

In the laboratory, animals were transferred to 30-50 l aquaria (macrofauna with some sediment from the collection site) with continuously flowing seawater ( 5 to $6 \mathrm{PSU}, 5$ to $10^{\circ} \mathrm{C}$ ) and with gentle aeration until initiating the experiments. Amphipods and mysids were always handled in dim light to protect their sensitive eyes.

Bioturbation experiment (BE). The experimental units in BE consisted of plexiglass cylinders (height $20 \mathrm{~cm}$, diameter $14 \mathrm{~cm}$ ) equipped with a movable bottom. The sediment was sieved through a series of 500, 200 and $100 \mu \mathrm{m}$ meshes to remove macrofauna and Bosmina ephippia $(\sim 400 \mu \mathrm{m})$ from smaller material. The 100 to $500 \mu \mathrm{m}$ fraction was put aside and kept at $5^{\circ} \mathrm{C}$ until collection of Bosmina eggs. The $<100 \mu \mathrm{m}$ 
fraction was homogenised by stirring, measured out to the experimental cores, 1.21 in each, producing a final sediment thickness of $\sim 6 \mathrm{~cm}$, and allowed to settle for $8 \mathrm{~d}$ at $5^{\circ} \mathrm{C}$. The cores were immersed in 901 basins, 6 cores in each, carefully filled with seawater. The water (5 to 6 PSU) was pumped from 7 to $8 \mathrm{~m}$ depth from a nearby archipelago area and was not likely to contain cladoceran benthic eggs, which do not remain suspended in water but sink to the bottom upon their release. The inflowing water was checked under a dissecting microscope, and no Bosmina ephippia were found. The water was allowed to flow through the basins, and aeration was added to each basin. During the incubation, the temperature (measured 3 times $\mathrm{wk}^{-1}$ ) was $8.2 \pm 0.9^{\circ} \mathrm{C}$ (mean $\pm \mathrm{SD}$ ), the flow rate (measured once weekly) was $370 \pm 80 \mathrm{ml} \mathrm{min}^{-1}$ (mean $\pm \mathrm{SD}$ ) and the oxygen concentration (measured once weekly with a VWR D0200 Portable Dissolved Oxygen and Temperature Instrument) was $11.1 \pm 0.3 \mathrm{mg} \mathrm{l}^{-1}$ (mean \pm $\mathrm{SD})$. To prevent the escape of the amphipods, polychaetes and mysids, all cores were capped with a steel net with $0.5 \mathrm{~mm}$ mesh size.

To separate Bosmina eggs from the 100 to $500 \mu \mathrm{m}$ sediment fraction, it was poured on a $100 \mu \mathrm{m}$ sieve, washed with sugar-water solution $(0.5 \mathrm{~kg}$ of sugar in 0.51 of water) into centrifuge tubes and centrifuged for $3 \mathrm{~min}$ at $906 \times g$. After centrifuging, ephippia remained floating in the supernatant and were easy to collect with a pipette. This 'sugar flotation method' does not harm cladoceran benthic stages (Onbé 1978). Ephippia ( $n=120)$ were pipetted into each core and distributed evenly onto the sediment. After $1 \mathrm{~h}, 160 \mathrm{ml}$ of sediment $(<100 \mu \mathrm{m})$ were added to each core to bury the eggs under a 0.5 to $1 \mathrm{~cm}$ thick sediment layer, approximating an average annual accumulation rate in the study area (Viitasalo \& Katajisto 1994, Heiskanen \& Tallberg 1999), and the sediment was allowed to settle overnight. Hatching of ephippia introduced to a depth of 0.5 to $1 \mathrm{~cm}$ should be inhibited (cf. Kankaala 1983); hence, eggs were not expected to hatch in the initial conditions.

Seven treatments $(n=5)$ were carried out: controls without animals, 3 treatments with only macrofaunaMonoporeia (treatment notation: Mo), Macoma (Ma) and Marenzelleria $(\mathrm{Mz})$ - and 3 treatments combining macrofauna with mysids (Mo + My, $\mathrm{Ma}+\mathrm{My}$ and $\mathrm{Mz}+\mathrm{My})$. The animal densities and sizes are defined in Table 1.

The 5 replicates of the 7 treatments were distributed each in a different basin, and within a basin the experi- mental units were randomly assigned to the different treatments. Macrofauna were introduced to the cores and left to rework the sediment in darkness for $22 \mathrm{~d}$. In the treatments with Mysis mixta, 1 mysid was added to each core on Day 22 for $3 \mathrm{~d}$. At the end of the incubations, the average thickness of the light brown oxidised layer was visually estimated and measured with a ruler. In addition, the maximum mixing depth by the animals was estimated on the basis of visible extensions of animal burrows or paths. The water above the sediment was carefully siphoned off and checked for ephippia. The upper $1 \mathrm{~cm}$ of the sediment was cut into two $0.5 \mathrm{~cm}$ slices and the rest into $1 \mathrm{~cm}$ slices. The slicing apparatus consisted of a piston attached to a stand and a separate cutting plate (following the principle of Hakala 1971). A core was attached to the piston, which pushed the sediment upwards. During the sectioning, the sediment sank slightly due to some loss of water. As a result, the deepest layer acquired was the 3 to $4 \mathrm{~cm}$ stratum.

Each slice was washed onto a $100 \mu \mathrm{m}$ mesh and the number of ephippia was counted under a dissecting microscope. The condition of the animals was defined on the basis of their motion (Macoma) or swimming behaviour (Monoporeia and Marenzelleria). The survival of Macoma was $97 \%$, while the other species were in good health. Animals were preserved in 5\% buffered formalin and measured for length. The number of recovered ephippia in the control cores was $100.6 \pm 3.1$ (mean $\pm \mathrm{SE}$ ). The predation rates of mysids on ephippia (ephippia $\mathrm{d}^{-1}$ ) were determined by subtracting the number of recovered ephippia in the treatments with mysids to the average recovery of ephippia in the corresponding treatments with only infauna.

Sediment oxygen profiles. In the $\mathrm{BE}$, the effect of the activities of macrofauna on the oxygen penetration depth in the sediment was investigated by measuring oxygen profiles with a Clark-type microelectrode

Table 1. Body sizes (mean $\pm \mathrm{SD}$ ) and densities (ind. core ${ }^{-1}$ and ind. $\mathrm{m}^{-2}$ ) of macrofauna and mysids used in the bioturbation and hatching experiments. Marenzelleria, Monoporeia and Mysis mixta were measured from the front of the head to the tip of the last setiger (Marenzelleria) or telson (Monoporeia and M. mixta). Macoma was measured across the maximum shell width

\begin{tabular}{|llrrrr|}
\hline \multirow{2}{*}{ Experiment } & \multirow{2}{*}{ Species } & \multicolumn{2}{c}{ Size } & $\mathrm{n}$ & \multicolumn{2}{c|}{$\begin{array}{c}\text { Density } \\
\end{array}$} & & $(\mathrm{mm})$ & $\mathrm{core}^{-1}$ & $\mathrm{~m}^{-2}$ \\
\hline Bioturbation & Monoporeia & $6.0 \pm 0.6$ & 267 & 30 & 1950 \\
(BE) & Macoma & $17.2 \pm 1.1$ & 117 & 12 & 780 \\
& Marenzelleria & $30.0 \pm 4.4$ & 20 & 3 & 190 \\
& Mysis mixta & $17.4 \pm 1.5$ & 15 & 1 & 65 \\
Hatching & Monoporeia & $7.0 \pm 0.8$ & 112 & 20 & 1960 \\
(HE) & & $7.0 \pm 0.8$ & 112 & 50 & 4900 \\
& Macoma & $16.9 \pm 1.3$ & 96 & 8 & 780 \\
\hline
\end{tabular}


(Unisense OX100). A micromanipulator was used to introduce the sensor (outer tip diameter 90 to $110 \mu \mathrm{m}$ ) vertically in the sediment at $0.5 \mathrm{~mm}$ intervals. The sensor current was measured by a high-sensitivity picoammeter (Unisense PA2000) and converted to $\mathrm{O}_{2}$ partial pressure values. The penetration depth of dissolved oxygen was estimated from the oxygen tension curves according to Glud et al. (2003). Three to 4 replicate profiles were measured in 3 replicate cores of each treatment (no measurements in the treatments with mysids), yielding a total of 9 to 10 profiles per treatment.

Hatching experiment (HE). The sediment used for the HE was sieved through $0.5 \mathrm{~mm}$ mesh to remove macrofauna (but not ephippia) and stirred to homogenise the distribution of cladoceran eggs. Two replicate samples of $50 \mathrm{ml}$ of the homogenised sediment were taken to determine the initial density of Bosmina ephippia. Ephippia were separated from sediment as in the BE (Onbé's sugar flotation method) and preserved in $70 \%$ ethanol for examination and counting under a dissecting microscope.

Experimental plexiglass cores (height $20 \mathrm{~cm}$, diameter $11.4 \mathrm{~cm}$ ) were filled with $600 \mathrm{ml}$ of homogenised sediment and $\sim 1.4 \mathrm{l}$ of $10 \mu \mathrm{m}$ filtered seawater (FSW), until the water surface reached $\sim 2 \mathrm{~cm}$ from the top margin of the core. Sediment was allowed to settle for $32 \mathrm{~h}$. The average final sediment depth was $3.7 \mathrm{~cm}$ at the end of the experiment. Gentle aeration through a thin needle was added right below the water surface to keep the oxygen content sufficiently high (>80\%) but to avoid disturbance at the sediment surface. In addition to the amphipod and bivalve densities used in the $\mathrm{BE}$, a higher amphipod density of 50 ind. $\operatorname{core}^{-1}$ was used ( $\mathrm{n}=4$; Table 1$)$. As in the BE, control cores $(\mathrm{n}=4)$ without macrofauna were included and treated in the same manner as cores with animals. Treatments were randomly distributed among the experimental units.

Cores were incubated in darkness in a temperaturecontrolled room $\left(3^{\circ} \mathrm{C}\right)$ for $21 \mathrm{~d}$ ('cold period'). Subsequently, the temperature was raised to $13^{\circ} \mathrm{C}$ for $5 \mathrm{~d}$ ('warm period'). At 2 to $4 \mathrm{~d}$ intervals, the water in each core was carefully siphoned off and replaced with new water. The water collected was poured on a $50 \mu \mathrm{m}$ sieve to collect hatched cladocerans. Water was removed 8 times during the cold period and once during the warm period. The samples were preserved in $5 \%$ buffered formalin. Prior to siphoning, the oxygen concentration in the water $\left(11.7 \pm 0.3 \mathrm{mg} \mathrm{l}^{-1}\right)$ was measured at $\sim 6 \mathrm{~cm}$ depth in the water (YSI Model 95 Handheld Dissolved Oxygen and Temperature System). All hatched individuals were counted under a dissecting microscope. A $200 \mu \mathrm{m}$ sieve capped with paper was lowered right above the sediment surface, ensuring a steady and slow water flow through the margins of the sieve and minimising sediment resuspension. At the end of the experiments, water was siphoned off, sediment was thoroughly mixed and a sediment sample of $40 \mathrm{ml}$ was taken with a syringe from 3 replicate cores to define the final cladoceran egg density. Benthic animals were checked for condition and measured for length as in the BE.

To determine the vertical distribution of eggs in the $0.5 \mathrm{~mm}$ sieved sediment after settling (the procedure used in the HE), an additional depth distribution control was included. Sieved and stirred sediment $(800 \mathrm{ml})$ was added to 3 plexiglass cores (height $20 \mathrm{~cm}$, diameter $14 \mathrm{~cm}$ ) with a movable bottom. The cores were filled with FSW and sediment was allowed to settle in darkness $\left(5^{\circ} \mathrm{C}\right)$. No macrofauna was added to the cores. After $36 \mathrm{~d}$, the sediment was sliced into four $0.5 \mathrm{~cm}$ (the upper $2 \mathrm{~cm}$ ) and one $1 \mathrm{~cm}$ sections down to $3 \mathrm{~cm}$ (other details as in the BE). A sediment sample of $40 \mathrm{ml}$ was taken with a syringe from each slice. The average density of Bosmina ephippia was $790 \pm$ $70 \mathrm{core}^{-1}$ (mean $\left.\pm \mathrm{SE}\right)$, corresponding to $5.1 \times 10^{4}$ ephippia $\mathrm{m}^{-2}$. Vertically, the density ranged from 1.3 to 1.9 ephippia $\mathrm{cm}^{-3}$, but the depth distribution was rather even throughout the layers, i.e. concentration of eggs at a certain depth was not observed (the difference in the egg density across the 5 depth strata in a 1 -way $F$-test: $\left.F_{4,10}=1.63, \mathrm{p}=0.24\right)$.

Statistical tests. For normally distributed and homoscedastic data, a parametric $t$-test or single- or 2-factor analysis of variance (ANOVA; F-test) was used to test the differences between 2 or more groups, respectively. Square-root and logarithmic transformations were used to fulfil the parametric assumptions. Otherwise, a nonparametric procedure (Mann-Whitney $U$-test) was applied. Multiple comparisons were made using a Tukey HSD post hoc test. All statistical analyses were done with SPSS 11.5 software.

\section{RESULTS}

\section{Sediment reworking by three benthic species (BE)}

Bioturbation patterns. In the $\mathrm{BE}$, distinctive sediment reworking patterns were observed among the 3 macrofaunal species. The mixing effect of Monoporeia was confined to the upper 1 to $2 \mathrm{~cm}$, whereas Macoma extended the mixed zone down to $\sim 5 \mathrm{~cm}$. Faecal pellets of the amphipods (diameter $\sim 200 \mu \mathrm{m}$ ) were mainly found in the sediment samples from the 2 uppermost strata ( 0 to 0.5 and 0.5 to $1 \mathrm{~cm}$ ), while bivalve pellets (diameter $\sim 300 \mu \mathrm{m}$ ) were recorded in the layers down to $3 \mathrm{~cm}$ depth. A $0.5 \mathrm{~cm}$ thick stratum could contain several 10000 pellets. In the cores with Marenzelleria, pellets (diameter $\sim 100 \mu \mathrm{m}$ ) were much less abundant 
but burrows were observed vertically all through the sediment. The topmost sediment layers were oxidised down to 1.7 to $2.7 \mathrm{~cm}$ depth; Macoma and mysids significantly deepened the light brown layer (Tables 2 \& 3).

Oxygen properties. The average depth of $\mathrm{O}_{2}$ penetration ranged from $2.2 \mathrm{~mm}$ in $\mathrm{Mz}$ and control to $3.2 \mathrm{~mm}$ in $\mathrm{Mo}$, and the average $\mathrm{O}_{2}$ concentrations at the sediment-water interface ranged from $1.6 \mathrm{ml} \mathrm{O}_{2} \mathrm{l}^{-1}$ in Ma and control to $2.0 \mathrm{ml} \mathrm{O}_{2} \mathrm{l}^{-1}$ in Mo (Table 2). The differences between the treatments were not statistically significant (Table 3).

Depth distribution and abundance of ephippia. In the $\mathrm{BE}$, the 3 macrofaunal species had different effects on the distribution of Bosmina benthic eggs (Table 4, Fig. 1). In the treatment with Marenzelleria, the distribution of ephippia was almost identical to the control cores, indicating that the activities of polychaetes did not translocate ephippia vertically. In contrast, Macoma significantly extended the distribution of ephippia into deeper layers, whereas Monoporeia caused a decrease in the number of eggs in the uppermost $0.5 \mathrm{~cm}$ stratum (Tables 4 \& 5, Fig. 1). Both Monoporeia and Macoma decreased the total number of ephippia by 48 and $22 \%$, respectively, and the effect of Monoporeia was stronger than that of Macoma (Table 4).

Table 2. Bioturbation experiment. Depth of the light brown (mixed) sediment layer $(n=5)$ and the $\mathrm{O}_{2}$ penetration depth $(n=3)$ and concentration $(n=3)$ at the sediment-water interface (mean $\pm \mathrm{SE}$ ). Mo: Monoporeia, Ma: Macoma, Mz: Marenzelleria, My: mysid

\begin{tabular}{|lllcc|}
\hline Treatment & \multicolumn{2}{c}{$\begin{array}{c}\text { Light brown layer } \\
(\mathrm{cm})\end{array}$} & $\begin{array}{c}\mathrm{O}_{2} \text { penetration } \\
(\mathrm{mm}) \\
\text { No mysids }\end{array}$ & $\begin{array}{c}\mathrm{O}_{2} \text { concentration } \\
\left(\mathrm{ml} \mathrm{l}^{-1}\right) \\
\text { No mysids }\end{array}$ \\
\hline Control & $1.9 \pm 0.1$ & & $2.2 \pm 0$ & $1.6 \pm 0.3$ \\
Mo/Mo $+\mathrm{My}$ & $2.1 \pm<0.1$ & $2.2 \pm<0.1$ & $3.2 \pm 0.4$ & $2.0 \pm 0.3$ \\
Ma/Ma $+\mathrm{My}$ & $2.3 \pm 0.2$ & $2.7 \pm 0.1$ & $2.7 \pm 0.7$ & $1.6 \pm 0.3$ \\
Mz/Mz $+\mathrm{My}$ & $1.7 \pm 0.2$ & $1.8 \pm 0.1$ & $2.2 \pm 0.1$ & $1.7 \pm 0.2$ \\
\hline
\end{tabular}

Table 3. Bioturbation experiment. Effects of macrofauna and mysids on various sediment parameters. ANOVA notations: 1 -f $=$ single-factor, $2-\mathrm{f}=2$-factor. Significant values in bold $(p<0.05)$. C: control. See Table 2 for other abbreviations

\begin{tabular}{|lrcrl|}
\hline Parameter & ANOVA & Factor & Between subject & \multicolumn{1}{c|}{ Tukey HSD } \\
\hline Oxidised layer & 2-f & Macrofauna & $F_{3,25}=15.7, \mathbf{p}<\mathbf{0 . 0 0 1}$ & C-Ma: $\mathbf{0 . 0 0 1}$ \\
& & & & Mo-Ma: $\mathbf{0 . 0 1 6}$ \\
& & & & Mo-Mz: $\mathbf{0 . 0 0 7}$ \\
& & Mysid & $F_{1,25}=4.6, \mathbf{p}=\mathbf{0 . 0 4 2}$ & \\
& & Interaction & $F_{2,25}=0.8, \mathrm{p}=0.46$ & \\
& & & \\
$\mathrm{O}_{2}$ penetration & 1-f & Macrofauna & $F_{3,8}=1.4, \mathbf{p}=0.32$ & \\
$\mathrm{O}_{2}$ concentration & 1-f & Macrofauna & $F_{3,8}=0.5, \mathbf{p}=0.72$ & \\
\hline
\end{tabular}

Ephippia recovered (no.)

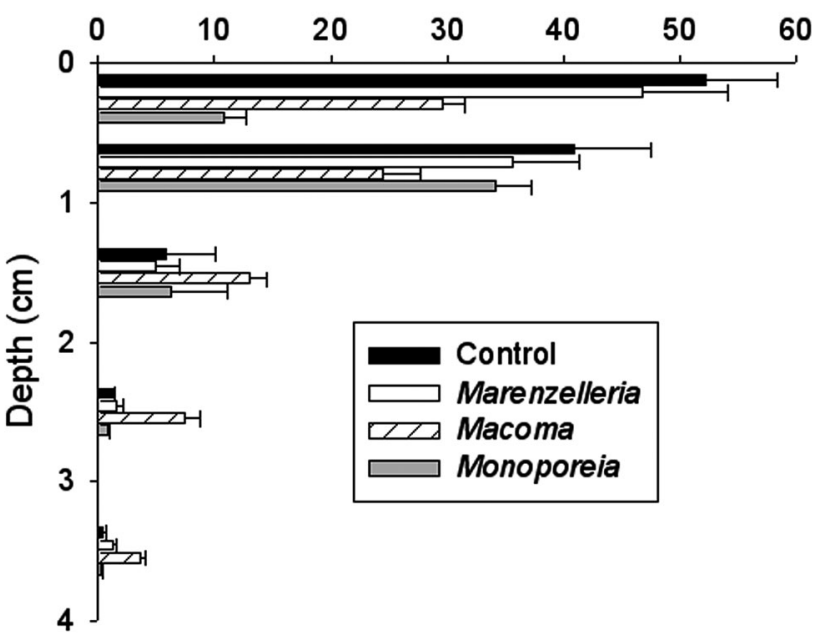

Fig. 1. Bosmina longispina maritima. Bioturbation experiment. Recovered cladoceran ephippia (no.) in each depth stratum in treatments without mysids (mean $\pm \mathrm{SE}$ )

\section{Epibenthic predation (BE)}

When Mysis mixta was added to the Monoporeia cores, the total recovery of ephippia declined slightly (from 52 to $44 \%$ ) but not significantly (Tables 4 \& 5). The calculated average predation rate of the mysids was $2.7 \pm 2.1$ ephippia $\mathrm{d}^{-1}$ (Mo + My compared to Mo). In the cores with Macoma or Marenzelleria, mysids caused no additional loss of ephippia (Tables 4 \& 5), indicating that benthic fauna did not bring ephippia within reach of the mysids. A few marginally significant differences, however, were found: Mysids appeared to increase Bosmina ephippia in the deepest sediment layer, suggesting additional burial, and the interaction term in the 2 to $3 \mathrm{~cm}$ layer and in the total recovery of ephippia indicated that the effect of macrofauna on cladoceran benthic eggs was affected by the presence of mysids (Table 4).

\section{Effects of macrofauna on hatching (HE)}

In the $\mathrm{HE}$, the average initial total density of Bosmina ephippia in the sediment was 3640 ephippia $\operatorname{core}^{-1}$, corresponding to $3.6 \times 10^{5}$ ephippia $\mathrm{m}^{-2}$ (Table 6). This is within the range 
of the field densities in the study area (Viitasalo \& Katajisto 1994). At the end of the experiment, the densities ranged from 2820 to 3060 ephippia core $^{-1}$ among the treatments, but these differences were not significant $\left(F_{3,8}=1.3, \mathrm{p}=0.35\right)$; differences between the ini-

Table 4. Bioturbation experiment. Effects of macrofauna and mysids (2-factor F-test) on Bosmina ephippia in different depth strata and on the total number of ephippia recovered. Significant values in bold $(p<0.05)$. See Tables $2 \& 3$ for abbreviations

\begin{tabular}{|c|c|c|c|}
\hline $\begin{array}{l}\text { Depth } \\
\text { (cm) }\end{array}$ & Factor & Between-subject & Tukey HSD \\
\hline \multirow[t]{2}{*}{$0-0.5$} & Macrofauna & $F_{3,28}=33.9, \mathrm{p}<\mathbf{0 . 0 0 1}$ & $\begin{array}{l}\text { C-Mo: }<\mathbf{0 . 0 0 1} \\
\text { C-Ma: } \mathbf{0 . 0 1 5} \\
\text { Mo-Ma: }<\mathbf{0 . 0 0 1} \\
\text { Mo-Mz: }<\mathbf{0 . 0 0 1} \\
\text { Ma-Mz: } \mathbf{0 . 0 1 0}\end{array}$ \\
\hline & $\begin{array}{l}\text { Mysid } \\
\text { Interaction }\end{array}$ & $\begin{array}{l}F_{1,28}=1.7, \mathrm{p}=0.20 \\
F_{2,28}=1.1, \mathrm{p}=0.35\end{array}$ & \\
\hline $0.5-1$ & $\begin{array}{l}\text { Macrofauna } \\
\text { Mysid } \\
\text { Interaction }\end{array}$ & $\begin{array}{l}F_{3,28}=3.2, p=\mathbf{0 . 0 3 9} \\
F_{1,28}<0.1, p=0.93 \\
F_{2,28}=2.0, p=0.16\end{array}$ & \\
\hline \multirow[t]{2}{*}{$1-2$} & Macrofauna & $F_{3,28}=5.7, p=\mathbf{0 . 0 0 4}$ & $\begin{array}{l}\text { C-Ma: } \mathbf{0 . 0 0 8} \\
\text { Mo-Ma: } \mathbf{0 . 0 2 4} \\
\text { Mz-Ma: } \mathbf{0 . 0 0 6}\end{array}$ \\
\hline & $\begin{array}{l}\text { Mysid } \\
\text { Interaction }\end{array}$ & $\begin{array}{l}F_{1,28}=1.5, \mathrm{p}=0.23 \\
F_{2,28}=2.3, \mathrm{p}=0.12\end{array}$ & \\
\hline \multirow[t]{2}{*}{$2-3$} & Macrofauna & $F_{3,28}=45.9, \mathrm{p}<\mathbf{0 . 0 0 1}$ & $\begin{array}{l}\text { C-Ma: }<\mathbf{0 . 0 0 1} \\
\text { Mo-Ma: }<0.001 \\
\text { Mz-Ma: }<\mathbf{0 . 0 0 1}\end{array}$ \\
\hline & $\begin{array}{l}\text { Mysid } \\
\text { Interaction }\end{array}$ & $\begin{array}{l}F_{1,28}<0.1, p=0.99 \\
F_{2,28}=3.4, p=\mathbf{0 . 0 4 9}\end{array}$ & \\
\hline \multirow[t]{2}{*}{$3-4$} & Macrofauna & $F_{3,28}=12.8, \mathrm{p}<\mathbf{0 . 0 0 1}$ & $\begin{array}{l}\text { C-Ma: }<\mathbf{0 . 0 0 1} \\
\text { Mo-Ma: }<0.001 \\
\text { Mz-Ma: } \mathbf{0 . 0 0 6}\end{array}$ \\
\hline & $\begin{array}{l}\text { Mysid } \\
\text { Interaction }\end{array}$ & $\begin{array}{l}F_{1,28}=4.0, p=0.054 \\
F_{2,28}=0.1, p=0.89\end{array}$ & \\
\hline \multirow[t]{2}{*}{ Sum } & Macrofauna & $F_{3,28}=52.2, \mathrm{p}<\mathbf{0 . 0 0 1}$ & $\begin{array}{l}\text { C-Mo: }<\mathbf{0 . 0 0 1} \\
\text { C-Ma: } \mathbf{0 . 0 2 0} \\
\text { Mo-Ma: }<\mathbf{0 . 0 0 1} \\
\text { Mo-Mz: }<\mathbf{0 . 0 0 1} \\
\text { Ma-Mz: } \mathbf{0 . 0 4 5}\end{array}$ \\
\hline & $\begin{array}{l}\text { Mysid } \\
\text { Interaction }\end{array}$ & $\begin{array}{l}F_{1,28}=2.0, \mathrm{p}=0.17 \\
F_{2,28}=3.3, \mathrm{p}=0.051\end{array}$ & \\
\hline
\end{tabular}

tial and final conditions were also not significant (control: $t=2.1, \mathrm{df}=3, \mathrm{p}=0.12$; Mo: $U=0.0, \mathrm{df}=3, \mathrm{p}=0.08$; Mo high: $t=2.8, \mathrm{df}=3, \mathrm{p}=0.07$; Ma: $t=1.9, \mathrm{df}=3, \mathrm{p}=$ 0.15). Almost no hatching occurred during the cold period (Days 0 to 21). After $21 \mathrm{~d}$, hatching was promoted by the raised temperature $\left(13^{\circ} \mathrm{C}\right.$ for $5 \mathrm{~d}$ ), and the average total number of hatched individuals per core ranged from 1 in Ma to 13 in the control (Table 6). Macrofauna significantly decreased Bosmina hatching rates $\left(F_{3,12}=8.4, \mathrm{p}=0.003\right) ;$ the reduction from the control cores was significant with Macoma (Tukey HSD, $\mathrm{p}=0.004$ ) and Monoporeia at the higher density (Tukey HSD, $\mathrm{p}=0.012$ ). Macoma caused the strongest decline, while the effect of Monoporeia was intensified at the higher amphipod density (although this increase was not significant; Mo vs. Mo high, Tukey HSD, $p=0.20$ ).

\section{DISCUSSION}

Many of the earlier studies investigating the effects of zoobenthos on resting stages of planktonic organisms have concentrated on vertical translocation of copepod eggs in the sediment by deposit-feeders (Marcus \& Schmidt-Gengenbach 1986, Albertsson \& Leonardsson 2000, 2001) or resistance of eggs to macrofaunal consumption (e.g. Marcus 1984). Predatory regulation of zooplankton and phytoplankton benthic propagules by macrofauna is relatively less studied (Parker et al. 1996, Cáceres \& Hairston 1998, Persson \& Rosenberg 2003). Furthermore, the impact of benthic fauna on zooplankton hatching has been widely discussed but rarely documented (Abertsson \& Leonardsson 2001, Ståhl-Delbanco \& Hansson 2002). Especially cladoceran benthic eggs have received little attention. To my knowledge,

Table 5. Bosmina longispina maritima. Bioturbation experiment. Number of cladoceran ephippia recovered in each depth stratum (mean $\pm \mathrm{SE}, \mathrm{n}=5$ )

\begin{tabular}{|c|c|c|c|c|c|c|c|}
\hline \multirow{2}{*}{$\begin{array}{l}\text { Depth } \\
\text { (cm) }\end{array}$} & \multirow[t]{2}{*}{ Control } & \multicolumn{2}{|c|}{ Monoporeia } & \multicolumn{2}{|c|}{ Macoma } & \multicolumn{2}{|c|}{ Marenzelleria } \\
\hline & & No mysids & Mysids & No mysids & Mysids & No mysids & Mysids \\
\hline $0-0.5$ & $52 \pm 6$ & $11 \pm 2$ & $7 \pm 3$ & $29 \pm 2$ & $24 \pm 2$ & $47 \pm 7$ & $51 \pm 8$ \\
\hline $0.5-1$ & $41 \pm 6$ & $34 \pm 3$ & $24 \pm 2$ & $24 \pm 3$ & $29 \pm 6$ & $35 \pm 6$ & $45 \pm 5$ \\
\hline $1-2$ & $6 \pm 4$ & $6 \pm 5$ & $12 \pm 5$ & $13 \pm 1$ & $19 \pm 1$ & $5 \pm 2$ & $3 \pm 1$ \\
\hline $2-3$ & $1 \pm 0$ & $1 \pm 0$ & $<1 \pm 0$ & $7 \pm 1$ & $12 \pm 2$ & $2 \pm 1$ & $1 \pm 0$ \\
\hline $3-4$ & $<1 \pm 0$ & $<1 \pm 0$ & $1 \pm 0$ & $4 \pm 1$ & $6 \pm 2$ & $1 \pm 0$ & $2 \pm 1$ \\
\hline Total & $101 \pm 3$ & $52 \pm 3$ & $44 \pm 6$ & $78 \pm 5$ & $89 \pm 2$ & $90 \pm 6$ & $102 \pm 4$ \\
\hline
\end{tabular}


Table 6. Bosmina longispina maritima. Hatching experiment. Egg densities and the number of hatched cladocerans during the cold $(21 \mathrm{~d})$ and warm $(5 \mathrm{~d})$ periods (mean $\pm \mathrm{SE}$ ). Eph.: ephippia; Mo high: amphipod density $=4900$ ind. $\mathrm{m}^{-2}$. See Table 2 for other abbreviations

\begin{tabular}{|lcccr|}
\hline Treatment & $\begin{array}{c}\text { Egg density } \\
\left.\text { (eph. core }{ }^{-1}\right)\end{array}$ & & \multicolumn{2}{c|}{$\begin{array}{c}\text { Hatched (ind. cor }{ }^{-1} \text { ) } \\
3^{\circ} \mathrm{C}\end{array}$} \\
\hline Initial & $3640 \pm 260$ & 2 & & \\
Control & $3060 \pm 150$ & 3 & $0.3 \pm 0.3$ & $12.5 \pm 1.7$ \\
Mo & $3260 \pm 30$ & 3 & 0 & $8.3 \pm 2.4$ \\
Mo high & $2820 \pm 180$ & 3 & 0 & $2.8 \pm 2.1$ \\
Ma & $2830 \pm 290$ & 3 & $0.3 \pm 0.3$ & $1.0 \pm 0.6$ \\
\hline
\end{tabular}

this is the first study to document the combined effect of translocation and predation of cladoceran ephippia by polychaetes, bivalves and amphipods.

\section{Effects of zoobenthos on ephippia in sediment}

Patterns of particle mixing, investigated with inert tracer introduced at the sediment surface, provide general insight into the impact of benthic infauna on sediment structure (e.g. François et al. 1997, 2002). In a study by Bradshaw et al. (2006), both Monoporeia and Macoma were classified as biodiffusers, which mix particles up and down within the few upper centimetres of the sediment. The average mixing depth of Monoporeia (8000 ind. $\mathrm{m}^{-2}$ ) was as high as $6 \mathrm{~cm}$, and the calculated particle mixing rate $\left(D_{b}\right)$ was double that of Macoma (1000 ind. $\mathrm{m}^{-2}$; Bradshaw et al. 2006). This is surprising given the practically non-existent downward transport of cladoceran eggs demonstrated in my study. While Monoporeia did not affect the distribution of ephippia in the deeper layers, it decreased their abundance in the sediment surface, resulting in a $48 \%$ reduction in the total number of eggs.

Monoporeia mainly inhabits and feeds on the top layers of the sediment (Lopez \& Elmgren 1989). It is not able to ingest particles $>60 \mu \mathrm{m}$ whole (Ankar 1977), although it may consume relatively large prey items, for example newly settled postlarval stages of $M a$ coma, by crushing them (Elmgren et al. 1986). The size of Bosmina ephippia corresponds to the size of postlarval Macoma ( 400 $\mu \mathrm{m}$; Elmgren et al. 1986), and thus would need to be crushed if ingested.

Bradshaw et al. (2006) found that Macoma buried tracer particles down to $4 \mathrm{~cm}$ depth, but its overall effect on particle profiles during the 3 wk experiment was relatively weak. Due to the non-conservative nature of ephippia, it is not possible to calculate the theoretical particle transport rates with them, but, on the basis of the egg distribution curves (Fig. 1), the vertical mixing of these large-sized resting stages by
Macoma was clearly much more effective than that caused by Monoporeia. Thus, the particle transport patterns demonstrated with various tracers may not be directly applied for viable objects with large and asymmetric dimensions such as cladoceran eggs.

Macoma generally occupies the uppermost $5 \mathrm{~cm}$ of the sediment, primarily feeding on deposited matter at the sediment surface (Lin \& Hines 1994) and may consume particles of up to $300 \mu \mathrm{m}$ (Gilbert 1977). The mechanism of egg translocation by Macoma is not obvious, but it is reasonable that the burrowing of this relatively large species mixes the sediment down to several centimetres depth, resulting in a more even depth distribution of eggs. Descriptive observations revealed that all ephippia buried by Macoma appeared intact, implying that they are not damaged by translocation by this species. Macoma also decreased the total number of cladoceran eggs by $23 \%$, indicating that some eggs were ingested. The presence of macrofauna may, however, evoke mechanisms other than consumption causing losses in the egg pool. Hence, detailed ingestion studies will be needed to determine the magnitude of zoobenthos predatory regulation on Bosmina ephippia.

Head-down positioned polychaetes may reintroduce copepod eggs (Marcus \& Schmidt-Gengenbach 1986) and dinoflagellate cysts (Giangrande et al. 2002) to the sediment-water interface. On the other hand, other polychaete species such as the galleryforming Nereis diversicolor transport tracer particles into deeper layers (François et al. 2002). To my knowledge, there are no data on the general particle mixing by Marenzelleria, but on the basis of its feeding and burrowing mode it resembles gallery-forming species in that it collects food mainly at surface sediments (Dauer et al. 1981) but burrows down to a depth of $35 \mathrm{~cm}$ (Zettler et al. 2002). Although burrows extending several centimetres in sediment might function as funnels for cladoceran eggs, in the current study, no effects of this polychaete were found on Bosmina ephippia, i.e. Marenzelleria seems unable either to feed on or transport particles of the size of cladoceran eggs.

Sexual reproduction in Bosmina mainly occurs in August to September (Purasjoki 1958, Kankaala 1983). The ephippia produced are not capable of hatching before termination of the diapause, probably lasting for 1 to $6 \mathrm{mo}$, and hatching generally starts in the following spring (Purasjoki 1958, Kankaala 1983). In this study, Monoporeia and Macoma decreased ephippia in the $0.5 \mathrm{~cm}$ thick sediment surface layer by 79 and $43 \%$, respectively, in $\sim 3 \mathrm{wk}$. Given the duration that Bosmina ephippia need to spend in the sea floor before they start to hatch, such faunal-mediated decline in the egg density is remarkable. 


\section{Effects of zoobenthos on Bosmina recruitment}

Albertsson \& Leonardsson (2001) found that Monoporeia inhibited the hatching of Bosmina and suggested that amphipods crushed ephippia or newly hatched cladocerans. In this study, Bosmina started to emerge during the $5 \mathrm{~d}$ period of raised temperature at the end of the HE. Due to the brief duration of the warm incubation, the overall hatching remained at a relatively low level. Compared to the control (13 hatched ind. core $\left.^{-1}\right)$, Monoporeia caused a 34 to $78 \%$ decline (8 to 3 ind. core $^{-1}$ ) in the total hatching, while the reduction caused by Macoma was $>90 \%$ (1 ind. core $^{-1}$ ). On the basis of the BE, the mechanism underlying these figures appears to differ between the 2 species: Monoporeia probably feeds on ephippia, whereas Macoma seems to have a combined effect of egg burial and predation (Fig. 2).

Apart from mechanical transport or damage, changes in the sediment chemistry may affect the fate and recruitment of planktonic propagules. Bioturbation by the isopod Asellus aquaticus and the chironomid Chironomus plumosus was shown to promote the germination of various phytoplankton taxa, most likely due to increased nutrient concentrations, whereas the hatching of cladocerans and copepods was not affected (Ståhl-Delbanco \& Hansson 2002). The presence of dissolved oxygen, generally limited to the upper few millimetres of the sediment (Revsbech et al. 1980), is a predominant factor controlling the hatching of zooplankton benthic eggs (Lutz et al. 1994, Katajisto 2004), contrary to phytoplankton cysts. The threshold

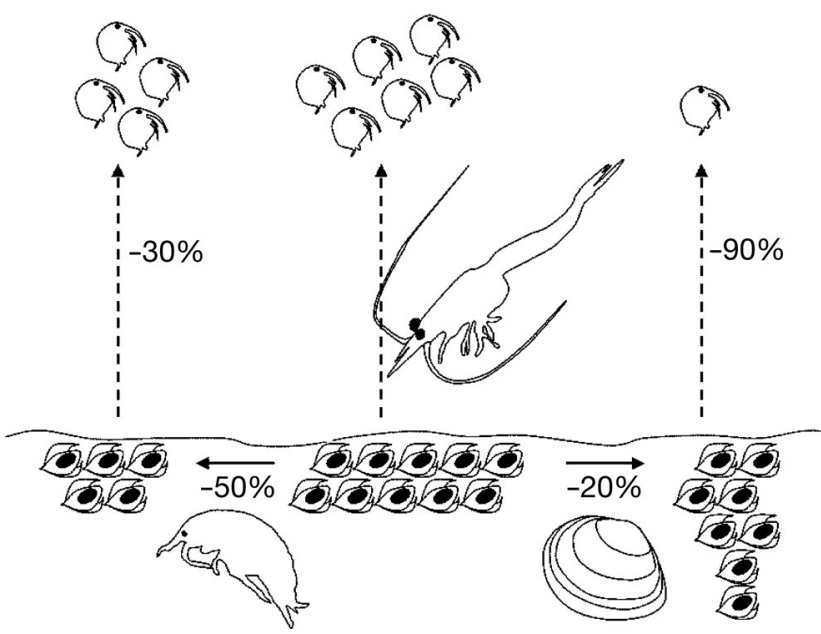

Fig. 2. Bosmina longispina maritima. Effects of Macoma (780 ind $\mathrm{m}^{-2}$ ) and Monoporeia (1950 ind. $\mathrm{m}^{-2}$ ) on the total abundance, vertical distribution and hatching of Bosmina ephippia. Solid arrows: reduction in the total number of ephippia caused by macrofauna (bioturbation experiment). Hatched arrows: reduction in the hatching of Bosmina (hatching experiment). The mysid is added for illustration oxygen concentration inhibiting the hatching of copepod eggs in sediments ranges between 0.10 and $0.20 \mathrm{ml} \mathrm{l}^{-1}$ (Lutz et al. 1994, Katajisto 2004), but corresponding data on cladoceran eggs are not available. In the $\mathrm{BE}$, there were no significant differences in $\mathrm{O}_{2}$ concentrations (1.6 to $2.0 \mathrm{ml} \mathrm{l}^{-1}$, depending on the treatment) at the sediment surface or in the penetration depth of $\mathrm{O}_{2}$ in sediment, which, in all treatments, was restricted to the upper $0.3 \mathrm{~cm}$. Thus, the effect of the slight increase in the $\mathrm{O}_{2}$ values caused by the amphipods was outweighed by the predatory effect, and may be ignored when interpreting differences in the hatching success of Bosmina.

Considering the abundance and vertical distribution of ephippia in the 2 experiments, the HE $\left(3.6 \times 10^{5}\right.$ eggs $\mathrm{m}^{-2}$, evenly distributed) mimicked natural conditions better than the $\mathrm{BE}\left(7800\right.$ eggs $\mathrm{m}^{-2}$, at 0.5 to $1 \mathrm{~cm}$ ). Burial of ephippia under 0.5 to $1 \mathrm{~cm}$ of sediment in the $\mathrm{BE}$, simulating a rapid sediment accumulation of the northern Baltic waters (Viitasalo \& Katajisto 1994, Heiskanen \& Tallberg 1999), possibly made them more available for Monoporeia (feeding on the top few centimetres) than for Macoma (collecting food mainly at the surface). In the BE, the amphipod density (1950 ind. $\mathrm{m}^{-2}$ ) that strongly decreased ephippia in the sediment surface (from 0 to $0.5 \mathrm{~cm}$ ) did not cause as large a decline in hatching in the HE. In contrast, Macoma had a dramatic effect on the hatching rate of Bosmina, indicating that at natural egg abundances distributed throughout the sediment the bivalves limit Bosmina recruitment more efficiently than the amphipods (Fig. 2). Zooplankton benthic eggs survive well in anoxic conditions (Katajisto 2004), and in the study area, viable Bosmina ephippia were found in 8 to $10 \mathrm{yr}$ old sediment layers (Viitasalo \& Katajisto 1994). Thus, in the field, the situation becomes more complicated; burial per se is not harmful to the eggs while predation is, i.e. buried eggs may still hatch at some future time if reintroduced to the sediment-water interface.

\section{Epibenthic predation by mysids}

As cladoceran eggs sink to the sea bottom, the rates of the sedimentation of organic matter, resuspension and bioturbation will determine how rapidly the eggs are buried under the sediment. According to Viitasalo \& Viitasalo (2004) Mysis mixta is unable to feed on ephippia buried in sediment; hence, it was suggested that bioturbation by macrofauna may essentially affect the predation by epibenthic mysids on their non-motile benthic prey. Consequently, one aim of this study was to test whether macrofauna could, by means of particle mixing, redistribute ephippia, buried under a sediment layer of 0.5 to $1 \mathrm{~cm}$, within the reach of the mysids. 
The feeding period of $72 \mathrm{~h}$ in the BE should have been enough to reveal any predatory effect since mysids may eat up to 61 cladoceran eggs ind..$^{-1}$ in only 12 h (Viitasalo \& Viitasalo 2004). However, except for the statistically insignificant additional decrease in ephippia $\left(<3 \mathrm{~d}^{-1}\right)$ in the treatment combining Monoporeia with mysids, no such effect was observed, i.e. macrofauna did not facilitate mysid predation on Bosmina ephippia. From these results, it can also be indirectly deduced that, since both Macoma and Monoporeia reduce the number of ephippia close to the sediment surface, they decrease the availability of Bosmina eggs as food for these bentho-pelagic predators.

Mysis mixta probably has no major effects on Monoporeia (Albertsson 2004), but epibenthic predators may affect the burrowing and feeding behaviour of Macoma (e.g. Bonsdorff et al. 1995). Despite the short period $(3 \mathrm{~d})$ of co-occurrence in this study, mysids seemed to increase the bivalve- and amphipodmediated egg burial and thereby affect the eventual fate of ephippia in the sediment.

\section{Long-term implications}

To estimate how the shift in the Baltic Sea benthic communities might affect the dynamics of Bosmina benthic eggs, we need to consider the historical trends in the zoobenthic populations as well as the different impacts the 3 benthic species have on Bosmina. Based on the findings of this study, the species most detrimental to Bosmina is Macoma, followed by Monoporeia; Marenzelleria is the least detrimental. Accordingly, the rapid spread of the polychaetes with a simultaneous crash of the amphipods, as demonstrated in the Åland archipelago (Perus \& Bonsdorff 2004) and the Gulf of Riga (Cederwall et al. 1999), should be favourable for Bosmina. In the study area, on the other hand, the recent change from moderate Monoporeia abundances (1000 to 6000 ind. $\mathrm{m}^{-2}$ during the $1970 \mathrm{~s}$ and $1980 \mathrm{~s} ;$ A. Laine pers. comm.) to dense Macoma beds (from nonexistent in the 1970s and 1980s to $\sim 1000$ ind $\mathrm{m}^{-2}$ in the $2000 \mathrm{~s}$; A. Laine pers. comm.) should affect Bosmina dynamics negatively. Notably, the expansion of the bivalve populations in the northern Baltic Sea has occurred in relatively shallow archipelago waters (Perus \& Bonsdorff 2004), which are the most important zones for Bosmina recruitment (Purasjoki 1958).

The dynamics of the 3 benthic species are linked together by a series of negative interactions: Monoporeia preys on the settling spat of Macoma (Elmgren et al. 1986), Macoma reduces the survival of Marenzelleria (Kotta et al. 2001), and sediments inhabited by
Marenzelleria are avoided by Monoporeia (Neideman et al. 2003), which is also competitively inferior to Marenzelleria (Kotta et al. 2001). In addition to environmental change and intraspecific fluctuations, such interactions presumably play a role in the succession of the soft bottom communities. Considering the success of Bosmina recruitment, it may be concluded that it is crucial whether areas previously occupied by amphipods eventually become colonised by bivalves or polychaetes.

Acknowledgements. I thank A. Hirvonen, J.-P. Pääkkönen, J. Lindeberg, C. Henricsson, S. Londesborough, M. Lehtiniemi, E. Lindén and M. Lindström for helping me in the field and in the laboratory. S. Hietanen offered advice on oxygen measurements. J. Rapo designed and manufactured the sediment slicing device, and T. Sjölund constructed the sieves used with the sediment. The Tvärminne Zoological Station is acknowledged for good laboratory facilities. I thank M. Viitasalo, M. Lehtiniemi, A. Norkko, J. Norkko and 4 reviewers for important and helpful comments on the manuscript. The study was financed by the Onni Talas Foundation.

\section{LITERATURE CITED}

Albertsson J (2004) Trophic interactions involving mysid shrimps (Mysidacea) in the near-bottom habitat in the Baltic Sea. Aquatic Ecol 38:457-469

Albertsson J, Leonardsson K (2000) Impact of a burrowing deposit-feeder, Monoporeia affinis, on viable zooplankton resting eggs in the northern Baltic Sea. Mar Biol 136: 611-619

Albertsson J, Leonardsson K (2001) Deposit-feeding amphipods (Monoporeia affinis) reduce the recruitment of copepod nauplii from benthic resting eggs in the northern Baltic Sea. Mar Biol 138:793-801

Ankar (1977) The soft bottom ecosystem of the northern Baltic proper with special reference to the macrofauna. Contributions from the Asko Laboratory, University of Stockholm, No. 19

Bastrop R, Blank M (2006) Multiple invasions-a polychaete genus enters the Baltic Sea. Biol Invasions 8:1195-1200

Bonsdorff E, Norkko A, Sandberg E (1995) Structuring zoobenthos: the importance of predation, siphon cropping and physical disturbance. J Exp Mar Biol Ecol 192: 125-144

Bradshaw C, Kumblad L, Fagrell A (2006) The use of tracers to evaluate the importance of bioturbation in remobilising contaminants in Baltic sediments. Estuar Coast Shelf Sci 66:123-134

Cáceres CE, Hairston NG Jr (1998) Benthic-pelagic coupling in planktonic crustaceans: the role of the benthos. Ergeb Limnol 52:163-174

Cederwall H, Jermakovs V, Lagzdins G (1999) Long-term changes in the soft-bottom macrofauna of the Gulf of Riga. ICES J Mar Sci 56 (Suppl.):41-48

Dauer DM, Maybury CA, Ewing RM (1981) Feeding behavior and general ecology of several spionid polychaetes from the Chesapeake Bay. J Exp Mar Biol Ecol 54:21-38

De Stasio BT Jr (1989) The seed bank of a freshwater crustacean: copepodology for the plant ecologist. Ecology 70 : $1377-1389$ 
Elmgren R, Ankar S, Marteleur B, Ejdung G (1986) Adult interference with postlarvae in soft sediments: the Pontoporeia-Macoma example. Ecology 67:827-836

François F, Poggiale JC, Durbec JP, Stora G (1997) A new approach for the modelling of sediment reworking induced by a macrobenthic community. Acta Biotheor 45: 295-319

François F, Gerino M, Stora G, Durbec JP, Poggiale JC (2002) Functional approach to sediment reworking by galleryforming macrobenthic organisms: modeling and application with the polychaete Nereis diversicolor. Mar Ecol Prog Ser 229:127-136

Giangrande A, Montresor M, Cavallo A, Licciano M (2002) Influence of Naineris laevigata (Polychaeta: Orbiniidae) on vertical grain size distribution, and dinoflagellate resting stages in the sediment. J Sea Res 47:97-108

Gilbert MA (1977) The behaviour and functional morphology of deposit feeding in Macoma balthica (Linne, 1758), in New England. J Molluscan Stud 43:18-27

Glud RN, Gundersen JK, Roye H, Joergensen BB (2003) Seasonal dynamics of benthic $\mathrm{O}_{2}$ uptake in a semienclosed bay: importance of diffusion and faunal activity. Limnol Oceanogr 48:1265-1276

Hakala (1971) A new model of the Kajak bottom sampler, and other improvements in the zoobenthos sampling technique. Ann Zool Fenn 8:422-426

Heiskanen AS, Tallberg P (1999) Sedimentation and particulate nutrient dynamics along a coastal gradient from a fjord-like bay to the open sea. 393:127-140

Kangas P, Byholm L, Stigzelius J (2001) Changes in zoobenthic communities. In: Kauppila P, Bäck S (eds) The state of Finnish coastal waters in the 1990s. The Finnish Environment. Edita, Helsinki, p 79-88

Kankaala P (1983) Resting eggs, seasonal dynamics, and production of Bosmina longispina maritima (P. E. Müller) (Cladocera) in the northern Baltic proper. J Plankton Res 5:53-69

Katajisto T (2004) Effects of anoxia and hypoxia on the dormancy and survival of subitaneous eggs of Acartia bifilosa (Copepoda: Calanoida). Mar Biol 145:751-757

Kotta J, Orav H, Sandberg-Kilpi E (2001) Ecological consequence of the introduction of the polychaete Marenzelleria cf. viridis into a shallow-water biotope of the northern Baltic Sea. J Sea Res 46:273-280

Laine A, Sandler H, Andersin AB, Stigzelius J (1997) Longterm changes of macrozoobenthos in the Gotland Basin and the Gulf of Finland (Baltic Sea) in relation to the hydrographical regime. J Sea Res 38:135-159

Lin J, Hines AH (1994) Effects of suspended food availability on the feeding mode and burial depth of the Baltic clam, Macoma balthica. Oikos 69:28-36

Lopez G, Elmgren R (1989) Feeding depths and organic absorption for the deposit-feeding benthic amphipods Pontoporeia affinis and Pontoporeia femorata. Limnol Oceanogr 34:982-991

Lutz RV, Marcus NH, Chanton JP (1994) Hatching and viability of copepod eggs at two stages of embryological development: anoxic/hypoxic effect. Mar Biol 119:199-204

Marcus NH (1984) Recruitment of copepod nauplii into the plankton: importance of diapause eggs and benthic processes. Mar Ecol Prog Ser 15:47-54

Editorial responsibility: Otto Kinne (Editor-in-Chief), Oldendorf/Luhe, Germany
Marcus NH, Boero F (1998) Minireview: the importance of benthic-pelagic coupling and the forgotten role of the life cycles in coastal aquatic systems. Limnol Oceanogr 43: 763-768

Marcus NH, Schmidt-Gengenbach J (1986) Recruitment of individuals into the plankton: the importance of bioturbation. Limnol Oceanogr 31:206-210

Neideman R, Wenngren J, Ólafsson E (2003) Competition between the introduced polychaete Marenzelleria sp. and the native amphipod Monoporeia affinis in Baltic soft bottoms. Mar Ecol Prog Ser 264:49-55

Onbé T (1978) Sugar flotation method for sorting the resting eggs of marine cladocerans and copepods from seabottom sediment. Bull Jpn Soc Sci Fish 44:1411

Onbé T (1985) Seasonal fluctuations in the abundance of populations of marine cladocerans and their eggs in the Sea of Japan. Mar Biol 87:83-88

Parker BR, Wilhelm FM, Schindler DW (1996) Recovery of Hesperodiaptomus arcticus populations from diapausing eggs following elimination by stocked salmonids. Can J Zool 74:1292-1297

Persson A, Rosenberg R (2003) Impact of grazing and bioturbation of marine benthic deposit feeders on dinoflagellate cysts. Harmful Algae 2:43-50

Perus J, Bonsdorff E (2004) Long-term changes in macrozoobenthos in the Åland archipelago, northern Baltic Sea. J Sea Res 52:45-56

Purasjoki KJ (1958) Zur Biologie der Brackwasserkladozere Bosmina coregoni maritima (P. E. Müller). Ann Zool Soc Zool-Bot Fenn 'Vanamo' 19:1-117

Revsbech NP, Sorensen J, Blackburn TH (1980) Distribution of oxygen in marine sediments measured with microelectrodes. Limnol Oceanogr 25:403-411

Rhoads DC (1974) Organism-sediment relations on the muddy sea floor. Oceanogr Mar Biol Annu Rev 12:263-300

Roast SD, Widdows J, Pope N, Jones MB (2004) Sediment-biota interactions: mysid feeding activity enhances water turbidity and sediment erodability. Mar Ecol Prog Ser 281:145-154

Ståhl-Delbanco A, Hansson LA (2002). Effects of bioturbation on recruitment of algal cells from the 'seed bank' of lake sediment. Limnol Oceanogr 47:1836-1843

Uye S, Kasahara S, Onbé T (1979) Calanoid eggs in seabottom muds. IV. Effects of some environmental factors on the hatching of resting eggs. Mar Biol 51:151-156

Viherluoto M, Kuosa H, Flinkman J, Viitasalo M (2000) Food utilisation of pelagic mysids, Mysis mixta and M. relicta, during their growing season in the northern Baltic Sea. Mar Biol 136:553-559

Viitasalo M, Katajisto T (1994) Mesozooplankton resting eggs: identification and vertical distribution in laminated and mixed sediments. Mar Biol 120:455-466

Viitasalo S, Viitasalo M (2004) Predation by mysid shrimps Mysis mixta and M. relicta on benthic eggs of Bosmina longispina maritima (Cladocera) in the northern Baltic Sea. Mar Ecol Prog Ser 281:155-163

Zettler ML, Daynus D, Kotta J, Bick A (2002) History and success of an invasion into the Baltic Sea: the polychaete Marenzelleria cf. viridis, development and strategies. In: Leppäkoski E, Gollasch S, Olenin S (eds) Invasive aquatic species of Europe: distribution, impacts and management. Kluwer Academic Publishers, Dordrecht, p 66-75

Submitted: March 30, 2006; Accepted: September 29, 2006 Proofs received from author(s): April 11, 2007 